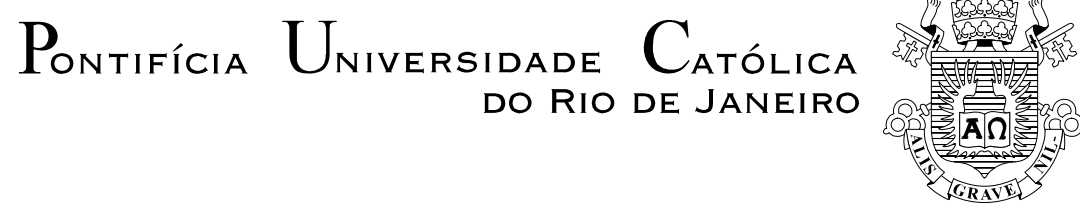

Paulo Calmon Nogueira da Gama

A desigualdade penal e a jurisdição na nova democracia brasileira

Dissertação de Mestrado

Dissertação apresentada como requisito parcial para a obtenção do título de Mestre pelo Programa de Pós-Graduação em Direito da PUC-Rio.

Orientador: Prof. João Ricardo W.Dornelles

Rio de Janeiro

Outubro de 2010. 


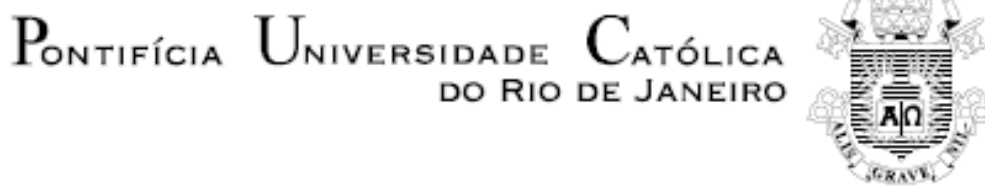

Paulo Calmon Nogueira da Gama

\section{A desigualdade penal e a jurisdição na nova democracia brasileira}

Dissertação apresentada como requisito parcial para obtenção do título de Mestre pelo Programa de Pósgraduação em Direito do Departamento de Direito da PUC-Rio. Aprovada pela Comissão Examinadora abaixo assinada.

Prof. João Ricardo Wanderley Dornelles

Orientador

Departamento de Direito - PUC-Rio

Prof. José Maria Gómez

Departamento de Direito - PUC-Rio

Profa. Bethânia de Albuquerque Assy

Departamento de Direito - PUC-Rio

Profa. Mônica Herz

Vice-Decana de Pós-Graduação do Centro de

Ciências Sociais - PUC-Rio

Rio de Janeiro, 04 de outubro de 2010. 
Todos os direitos reservados. É proibida a reprodução total ou parcial do trabalho sem autorização da Universidade, do autor e do orientador.

\section{Paulo Calmon Nogueira da Gama}

Graduado em Direito pela UCAM. Pós-graduado pela UGF. Procurador de Justiça do Estado de Minas Gerais (MP/MG)

Ficha Catalográfica

Gama, Paulo Calmon Nogueira da

A desigualdade penal e a jurisdição na nova democracia brasileira / Paulo Calmon Nogueira da Gama; orientador João Ricardo W. Dornelles - Rio de Janeiro: PUC, Departamento de Direito, 2010.

$123 f, 29,7 \mathrm{~cm}$

1. Dissertação (mestrado) - Pontifícia Universidade Católica do Rio de Janeiro, Departamento de Direito

Inclui referências bibliográficas.

1. Direito - teses. 2. Democracia brasileira. 3. Desigualdade. 4. Sistema penal. 5. Jurisdição criminal. I. Dornelles, João Ricardo W. II. Pontifícia Universidade Católica do Rio de Janeiro. Departamento de Direito. III. Título. 


\section{Agradecimentos}

Aos caríssimos professores do Programa de Pós-Graduação da PUC-Rio, verdadeiras referências de vida acadêmica e alicerces centrais das pesquisas aqui desenvolvidas, agradeço pela excelência do curso ministrado. Obrigado, Adriano Pilatti, Adrian Sgarbi, Bethânia Assy, Francisco de Guimaraens, Gisele Cittadino, José María Gómez, Márcia Nina Bernardes e Noel Struchiner, por serem quem são: exemplos de vocação e veneração à Academia e luminares generosos no compartilhar de seus imensuráveis saberes. Meu especial agradecimento ao prezado Professor João Ricardo W. Dornelles, não só pelas inesquecíveis e inspiradoras aulas, mas também pela preciosa orientação e pelo estímulo essencial para a realização deste trabalho. 


\section{Resumo}

Gama, Paulo Calmon Nogueira da. Dornelles, João Ricardo W. A desigualdade penal e a jurisdição na nova democracia brasileira. Rio de Janeiro, 2010. 123p. Dissertação de Mestrado - Departamento de Direito, Pontifícia Universidade Católica do Rio de Janeiro.

A enorme desigualdade social - ainda um traço marcante da realidade brasileira - repercute diretamente no fenômeno da criminalização. Mesmo com a redemocratização do País e a promulgação da Constituição mais "cidadã" de sua história, a questão criminal continua visivelmente imbricada aos indicadores de miséria e exclusão social. A atividade judicial, à luz do constitucionalismo hodierno, é dotada de potencialidades e ferramentas de correção ou atenuação do trato desigualitário e seletivo dispensado aos jurisdicionados por determinados dispositivos legais e pela administração estatal. A presente pesquisa - fincando suas bases em considerações extraídas, entre outras abordagens teóricas, da democracia deliberativa habermasiana, do marxismo e da criminologia crítica de Alessandro Baratta (reveladoras das desigualdades do sistema penal burguês) busca investigar o patamar de (in)efetividade do aparelho jurisdicional no manejo dessas ferramentas, no tocante às questões criminais que envolvam os predicados constitucionais dos cidadãos, em especial quanto ao tratamento isonômico e à coerência dos julgamentos. Constatados sinais de captura da função jurisdicional pela força conservadora da estrutura dominante, resulta agudizado o quadro de desigualdade e opressão do sistema penal e de desconfiança no aparelho judicial, inclusive em razão da utilização desmedida do poder discricionário, o que, em decorrência, reclama a busca por alternativas e mecanismos para a alteração desse cenário. Nesse sentido, ao final do trabalho são sugeridas posturas interpretativas e motivacionais destinadas ao refino do exercício da discricionariedade jurisdicional, sendo, ainda, apresentadas propostas voltadas à democratização da Justiça, à qualificação profissional e à constituição da subjetividade dos profissionais da área judicial.

\section{Palavras-chave}

Democracia brasileira; desigualdade penal; jurisdição criminal. 


\section{Abstract}

Gama Paulo Calmon Nogueira da. Dornelles, João Ricardo W (Advisor). Penal Inequality and Jurisdiction in the New Brazilian Democracy. Rio de Janeiro, 2010. 123p. MSc. Dissertation. Departamento de Direito, Pontifícia Universidade Católica do Rio de Janeiro.

Vast social inequality - still a noticeable characteristic in Brazil - continues to have repercussions on criminal behavior. Even with the re-democratization of the country and the most 'citizen-friendly' Constitution in its history, the question of crime is still related to indices of misery and social exclusion. Judicial activities, in the light of actual Constitutionalism, is replete with potential and corrective tools or attenuation of inequality or selective treaty dispensed to jurisdiction by determined legal devices and by state administration. This paper demonstrates some theoretical considerations, based on Habermas' deliberative democracy, Marxism and Alessandro Baratta's critique of crime (all revelations in the inequality of the bourgeois penal system); furthermore, the paper seeks to investigate the level of (in)efficiency of the jurisdictional device in managing these tools, touching on issues of criminal questions that involve citizen's constitutional predications, particularly isonomic treatment and the coherency of sentencing. Set signals of capture of the jurisdictional function by conservative forces of the current structure further heighten the factor of inequality and oppression of the penal system and shed doubt on the judicial system itself, including in the use of unmeasured discretional power, which, in turn, leads to the call for alternatives and actions to change the process. In the end of the paper, some interpretive and motivational positions are suggested in the hopes of refining the use of jurisdictional discretion, thus leading to some possible proposals leading toward democratization of Justice, professional training and the constitution of subjectivity of professionals in the judicial field.

\section{Keywords}

Brazilian democracy; penal inequality; criminal jurisdiction. 


\section{Sumário}

1. Introdução 8

2. Democracia e justiça 10

2.1. Democracia no Brasil em tempos de globalização 10

2.1.1. Expectativas em torno da Carta Cidadã 10

2.1.2. A reação neoliberal e o Estado Penal 12

2.2. Democracia mínima ou formal e suas insuficiências 17

2.3. Democracia deliberativa habermasiana 22

2.3.1. Sistema jurídico, imperativo inclusionista e inobstrução
da agenda

2.4. Protagonismo judicial. Tensão entre constitucionalismo e Democracia. Outra vez, o imperativo inclusionista 27

3. Desigualdade penal no Brasil 36

3.1. O mito da igualdade legal 36

3.2. Desigualdade na lei penal $\quad 39$

3.2.1. Considerações teóricas e inspirações marxistas 40

3.2.2. Considerações empíricas 45

3.3. Expansionismo da legislação criminalizante 54

3.3.1. Cultura do medo e a legislação de emergência 55

3.3.2. O big bang da legislação penal 58

3.4. Vigiar e controlar 62

3.5. Desigualdade na persecução pré-judicial: o Estado Policial e os buracos negros, cinzas e dourados da criminalidade $\quad 67$

4. Desigualdade jurisdicional criminal 73

4.1. Alcance desigual e (des)confiança na jurisdição 74

4.2. Fontes das desigualdades jurisdicionais $\quad 76$

4.2.1. Subjetivismo. Riscos e tendências conservacionistas 77

4.2.2. Sofismação motivacional: os códigos tecnológico e
ideológico

4.2.3. Posturas interpretativas: casos fáceis e discricionariedade
judicial

5. Controle e adequação jurisdicional 91

5.1. Controle de discricionariedade: imperativo motivacional

5.2. Posturas interpretativas: adequabilidade em razão da
matéria

5.3. Democratização e humanização da Justiça 104

6. Considerações finais 109

$\begin{array}{ll}\text { 7. Referências bibliográficas } & 115\end{array}$ 